\title{
Analysis of Pre-Service Social Sciences Teachers' Geography Perceptions through Metaphors: Case of Dumlupinar University
}

\author{
Süleyman Hilmi Şahin \\ Correspondence: Süleyman Hilmi Şahin, Dumlupınar University, Turkey
}

Received: October 26, 2015

Accepted: October 31, $2015 \quad$ Online Published: November 21, 2015

doi:10.11114/jets.v4i2.1163

URL: http://dx.doi.org/10.11114/jets.v4i2.1163

\begin{abstract}
The purpose of this study was to try to explain the perceptions of undergraduate students regarding geography concept using metaphors. A total of 192 students studying in the Department of Social Studies at Kütahya Dumlupınar University in the academic year 2014-2015 participated in this research. In the study following questions were searched to answer: (a) through which metaphors do undergraduate students explain the perceptions they have in relation to the concept of geography? (b) Under which categories are these metaphors collected in terms of common properties? The data in the study were obtained depending on students' answers to this sentence: "Geography is like... because...". In this research, phenomenological pattern were used and the data were analyzed by using content analysis technique. According to the findings of the research; (a) undergraduate students have produced 112 valid metaphors related to the concept of geography in total. (b) These metaphors by being examined in terms of common features were grouped under five different categories. As a result of the survey, it was observed that $\% 15,2$ of the students in Social Studies Department perceived the concept of geography as the source of life, $\% 32,2$ of them as part of the review of research, $\% 18,7$ as a reflection of the natural environment, $15,2 \%$ as nature and human interaction, $\% 18,7$ as entertainment factor. As a consequence, the metaphor related to the concept of geography could be used as a powerful research tool in understanding and explaining the perceptions concerning geography concept of undergraduate students.
\end{abstract}

Keywords: undergraduate, metaphor, geography education

\section{Introduction}

One of the basic goals of education is improving thinking skills and strategies to be used through their lives. So students need to acquire some basic qualifications along with their education. To do this, some new approaches and method \& techniques should be applied into educational system. Recently, some researches have been carried out on "metaphors" in education on all fields as well as geography education. Originating from the Latin "metaphora", the word "metaphor" is a combination of the word meta meaning extreme, and pherein meaning to bear, to carry. As a widely referred figure of speech, it is translated into Turkish as "eğretileme" (Salman, 2003). Metaphors are seen as a material to think, it is not only a shape of understanding of human and a figure of words but also a figure of thought (Lakoff \& Johnson, 2005). Interlinking two objects or concepts, a metaphor is considered to be a symbolic linguistic tool, providing transition from one life to another or make comparisons (Palmquist, 2001, 1). While a concrete or a physical concept is taken as the source for metaphors, abstract concepts are taken as the target. If we want to comprehend one concept better, we compare it to another concept that is more physical, tangible or concrete. For this very reason, sources and the targets stand still, which is applicable for a vast majority of the metaphors we use (Kövecses, 2002, 6). A good education should provide the students learning, remembering, motivating themselves and controlling their own learning, so that they can teach the ways of learning. For all these reasons, to investigate the process of the metacognitive skills of students is quite important Metaphors are also used in educational fields in addition to the cognitive fields and literature. Metaphors can help improve intuitional and emotional condition (Fraser, 2000, 12). When used in the field of education, metaphors offer a learning approach actively establishing the pattern of comprehension. According to this approach, students have to understand the similarities between what they already know and what they are learning. Then, they should be able to define the differences between what they just learned and its representation through metaphors. As metaphors have been used as analogies, allegories and similes, they are believed to function as a literary and artistic device. Yet, the metaphor is widely regarded as a tool to express or indicate our mental and intellectual understanding (Tuna and Budak, 2013).

Examining the prior literature, it is seen that metaphors have been used in different fields of education (Arslan and 
Bayrakçı, 2006; Botha, 2009; Aydın and Ünald1, 2010; Çapan, 2010; Döş, 2010; Forceville, 2002; Aydın, 2010; Guerrero and Villamil, 2002; Kaya, 2011; Cerit, 2008; Nalçacı and Bektaş, 2012; Öztürk, 2007; Saban, 2004; Saban et al., 2006; Saban, 2008; Saban, 2009; Shaw et al., 2008; Şeyhoğlu and Gencer, 2010; Şirin et al., 2012; Töremen and Döş, 2009; Yıldırım et al., 2011). It is also seen that various studies have been conducted in different disciplines of social sciences using metaphors. In relation to investigation of the concept of geography, there are also some studies in literature using metaphors. Öztürk (2007) applied a metaphor study of geography concept on the students of division of social sciences, primary education and science teaching; and Geçit and Gençer (2010) on students of division of primary education; and Aydın (2010) on students of division of middle school teaching. However, almost no studies are found focusing on the curricula taught to the students of the faculties of education. From this perspective, this study is believed to be the first. Aim of this study is to identify opinions of the students studying in the division of social sciences through metaphors.

\subsection{Introduce the Problem}

Attitudes of students studying in the division of social sciences in relation with the geography concept depend on their backgrounds. It is strongly believed that educators may be provided with valuable information and viewpoints by revealing the perceptions of the concept of geography, which is a comprehensive and abstract concept. The aim of this study is to elicit the pre-service social sciences teachers' perceptions of the concept of geography through metaphors. For this purpose, answers to the following questions were sought:

1. Which metaphors do the pre-service social sciences teachers use to express their perceptions of the concept of geography?

2. Which metaphors belong to which categories in terms of their common qualities?

\section{Method}

\subsection{Research Design}

"Phenomenological" qualitative research design is employed in this study. The phenomenological design is used to focus on issues that we are aware, yet do not have a deepened and detailed understanding what they are. We experience phenomena in different forms such as events, experiences, tendencies, perceptions, statuses and concepts. We may encounter these phenomena in our daily lives in quite different ways. However, we may not necessarily shake hands with the phenomena during this encountering. Phenomenology is a suitable field to analyze phenomena that we are almost familiar with or that we could not get the full meaning of (Yıldırım and Şimşek, 2013).

\subsection{Study Group}

This study covers 311 students studying in the Division of Social Sciences at the Education Faculty of Kütahya Dumlupınar University during fall semester in 2014-2015 academic years. Sample of the study was selected randomly. In this method, any member of the target group has equal chance to be selected. Samples are selected randomly from the target group list. What is important here is that all the members in the list should have common characteristics (Çepni, 2010). The research sample is formed of 192 students from the Division of Social Sciences at the Education Faculty of Kütahya Dumlupınar University (Table 1).

Table 1. Distribution of the students by gender

\begin{tabular}{lcc}
\hline Gender & Frequency (f) & Percentage (\%) \\
\hline Female & 98 & 51 \\
Male & 94 & 49 \\
Total & 192 & 100 \\
\hline
\end{tabular}

\subsection{Data Collection}

For data collection, former studies aiming to reveal participants' perceptions were analyzed (Saban 2004, 2008, 2009; Pishghadam et al., 2009; Alger, 2009; Cerit, 2008; Inbar, 1996; Kalyoncu, 2013; Aydoğdu, 2008; Öztürk, 2007; Guerrero and Villamil, 2002; Pishghadam and Navari, 2010; Saban et al., 2006; Semerci, 2007; Töremen and Döş, 2009; Shaw et al., 2008). In these studies, the participants were mostly asked to complete open-ended sentences. In some of these studies, in order to identify the pre-service social sciences teachers' perceptions of the concept of geography, they were asked to complete the sentences such as "Geography is like ..., because...". Students were given 20 minutes to write their metaphors on the concept of geography and their answers formed the databases of the researches.

\subsection{Data Analysis and Interpretation}

In this study, content analysis technique was employed for the analysis of collected data. The main reason for using this technique is to get concepts and connections that may explain the collected data. In content analysis, the data summarized and interpreted in the descriptive analysis are analyzed in a more detailed way and concepts and themes 
that cannot be recognized during the descriptive analysis are discovered as a result. In the essence of content analysis lies bringing similar data together within the context of certain concepts and themes, and then interpreting them by organizing in such a way that enables reader to easily understand them (Yıldırım and Şimşek, 2013). Metaphors developed by the students were analyzed and interpreted at five stages, which are (Yıldırım and Şimşek, 2013; Saban 2004, 2008, 2009): (a) Naming, (b) Classification, (c) Section Development, (d) Securing Validity and Reliability (e) Data Processing.

\subsubsection{Naming}

The metaphors created by the students were put into an alphabetical order in a temporary list. The metaphors written on the papers were analyzed to see whether they served for the intended use. The metaphors written by each student were classified under specific categories (such as guide, ocean, life, science, interaction ...) and put into an alphabetical order in a temporary list. Some students did not write any metaphors, and those papers were excluded.

\subsubsection{Classification}

In this stage, each metaphor was deepened by using "metaphor analysis" technique and the metaphors were analyzed separately in terms of their similarities and differences with the other metaphors. For this purpose, each metaphor produced by the students was analyzed in terms of; 1-its topic, 2-its source, 3-relationship between its topic and its source. Out of 192 students, 112 valid metaphors were collected. These metaphors were again put into an alphabetical order, the raw data were revised, and then by combining the statements in the samples that represents the metaphors best, sample metaphor list was created. This list was formed on two objectives: 1- for use as a source of reference for the classification of the metaphors under certain sections and 2- for validating the data analysis process and the thereof.

\subsubsection{Section Development}

In this stage, metaphors created by the participants were analyzed in terms of their common characteristics. The list made up of 112 metaphors created by the students was analyzed; all of these metaphors were gathered under a certain theme related to geography, constituting 5 totally different sections. For example, all of the metaphors classified under the "Geography as a Research and Investigation Element" section take geography as an element of research and investigation. Sky From this perspective, "Concept of geography pushes us to sail for the unknown seas, get familiar with an undiscovered island or our environment; besides it may lead us to observe the universe.

\subsubsection{Securing Validity and Reliability}

In order to enhance the credibility of the research findings, it is of great importance to explain how the results of the research were obtained and to report the collected data in a detailed manner. Securing validity and reliability is one of the most widely used criteria in qualitative studies (Yıldırım and Şimşek, 2013). In this stage, metaphors were classified into five. Whether metaphors validate these five sections or not was checked by the expert opinion. The metaphors lists were grouped under topics covering the points in common. Then, the classifications by the expert and the ones by the researchers were compared. After that, the number of shared and contrary parts were determined. The reliability of the study was calculated through this formula: "Reliability $=(($ shared):(shared+contrary) $) \times 100 "($ Miles and Huberman, 1994). In qualitative researches, when the intersection of the evaluations by the researchers and the experts is $90 \%$ or higher, then the reliability is considered to be secured (Saban, 2009). In this study, differences were found in 9 metaphors in terms of researcher's and experts' classifications. Thus, the reliability of this study was calculated and secured as follows: Reliability $=((112) /(112+9) \times 100=0.93(\% 0.93)$.

\subsubsection{Data Processing}

The data received from the students were analyzed and classified and 112 metaphors were selected. Out of them, five conceptual sections were developed and the data were entered into a computer. Then the number of participants (f) and percentage of participants representing 112 metaphors and 5 sections were calculated. 
Table 2. Percentage and number of students from the division of social sciences who created valid metaphors, in alphabetical order

\begin{tabular}{|c|c|c|c|}
\hline Order & Metaphor & $\begin{array}{c}\text { Frequency } \\
\text { (f) }\end{array}$ & $\begin{array}{c}\text { Percentage } \\
(\%)\end{array}$ \\
\hline 1 & Tree & 1 & .52 \\
\hline 2 & Finding the infinite one & 1 & .52 \\
\hline 3 & A formidable sea & 1 & .52 \\
\hline 4 & Love & 1 & .52 \\
\hline 5 & Mirror & 1 & .52 \\
\hline 6 & What you see depends on where you stand & 1 & .52 \\
\hline 7 & Culture improving me & 1 & .52 \\
\hline 8 & Valuable for me & 1 & .52 \\
\hline 9 & Brain & 1 & .52 \\
\hline 10 & Scientific method & 1 & .52 \\
\hline 11 & Sailing to uncharted seas & 1 & .52 \\
\hline 12 & An island waiting to be discovered & 1 & .52 \\
\hline 13 & All sciences have in common & 1 & .52 \\
\hline 14 & Map that lives & 1 & .52 \\
\hline 15 & Eden's garden & 1 & .52 \\
\hline 16 & Nut & 2 & 1.04 \\
\hline 17 & Environment & 1 & .52 \\
\hline 18 & Getting familiar with where we live & 1 & .52 \\
\hline 19 & Flowers -insects & 1 & .52 \\
\hline 20 & Chocolate & 1 & .52 \\
\hline 21 & Sea & 3 & 1.56 \\
\hline 22 & Lighthouse & 1 & .52 \\
\hline 23 & Nature & 1 & .52 \\
\hline 24 & Natural beauty & 1 & .52 \\
\hline 25 & Cycle & 1 & .52 \\
\hline 26 & The Earth & 1 & .52 \\
\hline 27 & Mirror of the Earth & 1 & .52 \\
\hline 28 & Living in anywhere in the world & 1 & .52 \\
\hline 29 & The world itself & 1 & .52 \\
\hline 30 & Understanding the world & 1 & .52 \\
\hline 31 & Experiencing the world on travel & 1 & .52 \\
\hline 32 & Exploring the world & 1 & .52 \\
\hline 33 & Thinking & 1 & .52 \\
\hline 34 & Is fun & 1 & .52 \\
\hline 35 & Science of effect & 1 & .52 \\
\hline 36 & Interaction-communication & 1 & .52 \\
\hline 37 & Understanding the universe & 1 & .52 \\
\hline 38 & Science that focuses on the universe and the Earth & 1 & .52 \\
\hline 39 & Art of interpreting the universe & 1 & .52 \\
\hline 40 & Rainbow & 1 & .52 \\
\hline 41 & Sky & 1 & .52 \\
\hline 42 & Observatory & 1 & .52 \\
\hline 43 & A planet in the solar system & 1 & .52 \\
\hline 44 & A tool facilitating daily life & 1 & .52 \\
\hline 45 & Map & 2 & 1.04 \\
\hline 46 & Life & 10 & 5.2 \\
\hline 47 & Our source of life & 1 & .52 \\
\hline 48 & A medicine that corrects our approach to life & 1 & .52 \\
\hline 49 & A part of my life & 1 & .52 \\
\hline 50 & Hobby & 1 & .52 \\
\hline 51 & River & 1 & .52 \\
\hline 52 & Hologram of the world & 1 & .52 \\
\hline 53 & Inspector & 1 & .52 \\
\hline 54 & Human & 1 & .52 \\
\hline 55 & Human-nature relationship & 9 & 4.68 \\
\hline 56 & Human-nature competition & 1 & .52 \\
\hline 57 & Human body & 1 & .52 \\
\hline 58 & Everything that belongs to human and nature & 1 & .52 \\
\hline 59 & Human's relationship with physical and social nature & 3 & 1.56 \\
\hline 60 & Harmony of humans with their environment & 3 & 1.56 \\
\hline
\end{tabular}


Table 2 continued

\begin{tabular}{|c|c|c|c|}
\hline 61 & Humans exploring where they live & 1 & .52 \\
\hline 62 & The Earth human relationship & 1 & .52 \\
\hline 63 & Human Experiences & 1 & .52 \\
\hline 64 & Skeletal system & 1 & .52 \\
\hline 65 & Hypsometry & 1 & .52 \\
\hline 66 & Getting lost & 1 & .52 \\
\hline 67 & Pathfinder & 1 & .52 \\
\hline 68 & Girl friend & 1 & .52 \\
\hline 69 & Queen bee & 1 & .52 \\
\hline 70 & Human that embraces others & 1 & .52 \\
\hline 71 & Cultural navigation & 1 & .52 \\
\hline 72 & Labyrinth & 1 & .52 \\
\hline 73 & Mathematics & 1 & .52 \\
\hline 74 & Picklock & 1 & .52 \\
\hline 75 & Hometown & 1 & .52 \\
\hline 76 & Casque & 1 & .52 \\
\hline 77 & Nation & 1 & .52 \\
\hline 78 & Motor vehicle & 1 & .52 \\
\hline 79 & My motorcycle & 1 & .52 \\
\hline 80 & The boat in the middle of the ocean & 1 & .52 \\
\hline 81 & Ocean & 7 & 3.64 \\
\hline 82 & Teacher & 1 & .52 \\
\hline 83 & Orange & 1 & .52 \\
\hline 84 & Puzzle & 1 & .52 \\
\hline 85 & Guide & 9 & 4.68 \\
\hline 86 & Art & 1 & .52 \\
\hline 87 & Infinite loop & 1 & .52 \\
\hline 88 & Infinite source & 1 & .52 \\
\hline 89 & Water & 6 & 3.12 \\
\hline 90 & Water, air, soil, sun & 2 & 1.04 \\
\hline 91 & Password & 1 & .52 \\
\hline 92 & Nature & 11 & 5.72 \\
\hline 93 & Identification & 1 & .52 \\
\hline 94 & History & 1 & .52 \\
\hline 95 & Technology & 1 & .52 \\
\hline 96 & Fundamental source & 1 & .52 \\
\hline 97 & Tourism & 1 & .52 \\
\hline 98 & Turkish and mathematics combination & 1 & .52 \\
\hline 99 & A flying sky & 1 & .52 \\
\hline 100 & Never-ending eternity & 1 & .52 \\
\hline 101 & Getting to know our country and the world & 1 & .52 \\
\hline 102 & The book covered in dust & 1 & .52 \\
\hline 103 & Our country & 1 & .52 \\
\hline 104 & Living & 16 & 8.32 \\
\hline 105 & Philosophy of life & 1 & .52 \\
\hline 106 & Everything about life & 1 & .52 \\
\hline 107 & A living planet & 1 & .52 \\
\hline 108 & Geology & 8 & 4.16 \\
\hline 109 & Description of the Earth & 4 & 2.08 \\
\hline 110 & Swimming & 1 & .52 \\
\hline 111 & My favorite course & 1 & .52 \\
\hline 112 & Is like an enjoyable mathematics lesson & 1 & .52 \\
\hline TOTAL & & $100(\mathrm{f})^{1 *}$ & $100(\%)$ \\
\hline
\end{tabular}

\section{Results}

In this section, the findings achieved in relation with the metaphors created by students studying in the division of social sciences on Geography were tablulated and classified into topics, analyzed, and interpreted. In Table 2, the metaphors created by the students are put into an alphabetical order and the number of students in each metaphor is presented therein. The students produced 112 valid metaphors related with the concept of geography. 86.6\% ( $\mathrm{n}=97$ ) of these metaphors was created by only one student. The remaining metaphors $(n=15)$ were created by 2 to 16 students.

3.1 Findings Related with the Metaphors Created by the Pre-service Social Sciences Teachers on the Concept of Geography

The metaphors created more than once by the students are as follows: Living (16 students, $8.32 \%$ ), Nature (11 students, 
$5.72 \%$ ), Life (10students, 5.2\%), Human-nature relationship (9 students, 4.68\%), Guide (9 students, $4.68 \%$ ), Water (6 students, $3.12 \%$ ), relationship between humans and the environment, Chocolate, Synergy of humans with their physical and social nature (3 students, 1.56\%), Map, nut, water, air, soil (2 students, $1.04 \%$ ). These metaphors are presented in Table 2 .

Sections of the Metaphors Created by the Pre-service Social Sciences Teachers in relation with the Concept of Geography: The metaphors created by the participants were classified under five sections, which are geography as our source of life, an element of research and investigation, reflection of natural environment, nature and human interaction and an element of fun. The data belonging to these sections are given in Table 3.

Table 3. Sections of metaphors created by the pre-service social sciences teachers on the concept of geography

\begin{tabular}{|c|c|c|c|}
\hline Sections & Metaphors & Student & Metaphor \\
\hline Our source of life & $\begin{array}{l}\text { Human's relationship with physical and social nature-3, Love-1, } \\
\text { Everything that belongs to human and nature-1, Water }-6 \text {, Guide-9, } \\
\text { Human-nature relationship- } 9 \text {, Scientific method- } 1 \text { Orange-1, Sea-3, } \\
\text { Human-nature competition-1, Environment }-1 \text {, Living-16, Living } \\
\text { in anywhere of the world-1, Life-10, Our source of life }-1 \text {, A } \\
\text { formidable sea }-1 \text {, Hologram of the world-1, Cultural navigation-1, } \\
\text { Hobby-1. }\end{array}$ & 68 & 19 \\
\hline $\begin{array}{l}\text { Element of research } \\
\text { and investigation }\end{array}$ & $\begin{array}{l}\text { Mirror-1, Culture improving me-1, Valuable for me }-1 \text {, Sailing in } \\
\text { uncharted seas }-1 \text {, Eden's garden }-1 \text {, Nut }-2 \text {, An island waiting } \\
\text { to be discovered }-1 \text {, , Getting familiar with where we live }-1 \text {, Nature }-1 \text {, } \\
\text { Natural beauty }-1 \text {, Fun } 1 \text {, Interaction-communication }-1 \text {, Getting to } \\
\text { know the universe }-1 \text {, Science investigating the universe and The Earth } \\
-1 \text {, Sky }-1 \text {, Observatory }-1 \text {, Map }-2 \text {, Inspector }-1 \text {, Relationship of } \\
\text { humans with the Earth }-1 \text {, Skeletal system }-1 \text {, Picklock }-1 \text {, Casque } \\
-1 \text {, My motorcycle }-1 \text {, The boat in the middle of the ocean }-1 \text {, } \\
\text { Ocean }-7 \text {, Teacher }-1 \text {, Puzzle-1, Password }-1 \text {, Nature }-11 \text {, } \\
\text { Fundamental source }-1 \text {, Turkish and mathematics combination }-1 \text {, } \\
\text { Never-ending eternity }-1 \text {, Our country }-1 \text {, Geology }-8 \text {, My favorite } \\
\text { course }-1 \text {. }\end{array}$ & 60 & 35 \\
\hline $\begin{array}{l}\text { Reflection of natural } \\
\text { environment }\end{array}$ & $\begin{array}{l}\text { Tree }-1 \text {, Brain }-1, \quad \text { Map that lives }-1 \text {, Flowers-insects }-1 \text {, The } \\
\text { world itself }-1, \quad \text { A tool facilitating daily life }-1 \text {, River }-1 \text {, } \\
\text { Hypsometry-1, Getting lost }-1 \text {, Girlfriend }-1 \text {, Queen bee }-1 \text {, Human that } \\
\text { embraces others }-1 \text {, Mathematics }-1 \text {, Motor vehicle }-1 \text {, Art } \\
-1 \text {, Infinity loop-1, Getting to know }-1 \text {, History }-1 \text {, Technology }-1 \text {, } \\
\text { The book covered in dust }-1 \text {, } \\
\text { A living planet }-1 \text {, }\end{array}$ & 21 & 21 \\
\hline $\begin{array}{l}\text { Nature and human } \\
\text { interaction }\end{array}$ & $\begin{array}{l}\text { Finding the infinite one }-1 \text {, World }-1 \text {, Mirror of the world }-1 \text {, } \\
\text { What you see depends on where you stand }-1 \text {, Tourism }-1 \text {, } \\
\text { Understanding the world }-1 \text {, Everything about life-1, A part of my life } \\
- \text {, } 1 \text { Experiencing the world on travel }-1 \text {, Human }-1 \text {, Art of } \\
\text { interpreting the universe }-1 \text {, Hometown }-1 \text {, A planet in the solar } \\
\text { system }-1 \text {, Water, air, soil, sun }-2 \text {, A medicine that corrects our approach } \\
\text { to life }-1 \text {, Harmony of humans with their environment }-3 \text {, Infinite } \\
\text { source }-1 \text {, Getting to know our country and the world }-1 \text {, Is like an } \\
\text { enjoyable mathematics lesson }-1 \text {. }\end{array}$ & 22 & 19 \\
\hline Element of fun & $\begin{array}{l}\text { All sciences have in common }-1 \text {, Chocolate }-1 \text {, Lighthouse }-1 \text {, Cycle-1, } \\
\text { Discovering the world }-1 \text {, Thinking }-1 \text {, Nation }-1 \text {, } \\
\text { Science of effect }-1 \text {, Rainbow }-1 \text {, Human body }-1 \text {, Swimming }-1 \text {, } \\
\text { Humans exploring where they live }-1 \text {, Experiences }-1 \text {, } \\
\text { Pathfinder }-1 \text {, Labyrinth-1, A flying sky }-1 \text {, Philosophy of life }-1 \text {, } \\
\text { Description of the Earth the Earth }-4 \text {, }\end{array}$ & 21 & 18 \\
\hline Total & & 192 & 112 \\
\hline
\end{tabular}

3.1.1 Section 3. Geography as the Reflection of Natural Environment

According to the metaphors presented in this section, geography is taken as the reflection of natural environment. The students associated the concept of geography with various objects within their environment. While some students resembled geography to things such as tree, flowers-insects, river, queen bee, others took it as reflection of the natural environment we live in, such as Human that embraces others, getting lost, girlfriend, infinity loop. In this section, 21 metaphors were created by 21 students (Tree, -1, Brain -1, Map that lives -1, Flowers-insects -1, The world itself -1, A tool that facilitates daily life -1, River -1, Hypsometry-1, Getting lost -1, Girlfriend -1, Queen bee -1, Human that embraces others -1, Mathematics -1, Motor vehicle -1, Art -1, Infinity loop -1, Getting to know -1, History -1, Technology -1, The book covered in dust -1, A living planet -1). Relevant examples on the metaphors are given below.

"Geography is like a tree, because all the branches of a tree are connected to each other. The topics of geography make 
the world meaningful."

"Geography is like art, because life is built on information. A life would be impossible without making use of geography."

"Geography is like an infinity loop, because it does not mean anything for those not reading it."

"Geography is like hypsometry, because it changes all the time."

\subsubsection{Section 4. Geography as Nature-Human Interaction}

In this section, there are metaphors created by students that consider geography as a part to the nature-human interaction. In this section, there are 19 metaphors generated by 22 students (Finding the infinite one -1 , What you see depends on where you stand-1, World -1, Mirror of the world -1, Understanding the world -1, Experiencing the world on travel-1, Art of interpreting the world -1, A planet in the solar system -1, A medicine that corrects our approach to life -1, A part of my life -1, Human -1, Harmony of humans with their environment -3, Hometown -1, Infinite source -1, Water, air, soil, sun -2 , Tourism -1 , Getting to know our country and the world -1, Everything about life -1 , Is like an enjoyable mathematics lesson-1). Relevant examples on the metaphors are given below.

"Geography is like a man living in harmony with his environment, because it examines the world and everything in it."

"Geography is everything about life, because it includes the invisible and millions of pieces of information."

"Geography is like understanding the world, because humans are not alone in this universe. They are responsible for the protection of it.

\subsubsection{Section 5. Geography as an Element of Fun}

The metaphors created by the students taking geography as an element of fun are presented in this section. Geography was associated with enjoyable elements by the students. These elements are chocolate, rainbow, swimming and cycle. In this section, there are 18 metaphors generated by 21 students (All sciences have in common -1, Chocolate -1 , Lighthouse -1, Cycle -1, Exploring the Earth -1, Thinking -1, Science of effect -1, Rainbow -1, Human body -1, Humans exploring where they live -1, Experiences -1, Pathfinder -1, Labyrinth-1, Nation -1, A flying sky -1, Philosophy of life -1,Description of the Earth -4, Swimming -1). Relevant examples of the metaphors are given below:

"Geography is like chocolate, because it makes you smile. One who discovers it feels as if he/she has discovered himself/herself."

"Geography is like swimming, because we should let it flow."

"Geography is like a rainbow, because the deeper you go, the more unknown are revealed."

"Geography is like discovering the Earth, because discovery is enjoyable. It explores the relationships between humans and places."

\section{Discussion}

In this study, 122 metaphors generated by the pre-service social sciences teachers were classified under five sections. These metaphors demonstrate the pre-service social sciences teachers' awareness of geography. On the basis of the metaphors generated by the students (Map that lives, Brain, Flowers-insects, The world itself, Pathfinder, Labyrinth, Nation, A flying sky, Tree, Philosophy of Life, Ocean, Teacher, Puzzle, Password, Nature, Fundamental source etc.), it can be expressed that geography, which is a multi-dimensional concept, cannot be explained with a single metaphor.

Pre-service social sciences teachers take courses about physical, human and economic geography from beginning from their first year. It was observed that through the sentence completion activity "geography is like ...because...", the participants revealed their prior knowledge and what they had learned during their university education.

It was determined that $35 \%$ of of 192 participants consider geography as "Our source of life", $31 \%$ consider it as "a research and investigation element", $12 \%$ consider it as "reflection of natural environment", $11 \%$ consider it as "human-nature interaction" and $11 \%$ consider it as "an element of fun". So, it may be understood that $89 \%$ of the participants are in interaction with nature in compliance with the definition of the geography. It may be said that humans has to be responsive to what is happening in their environment, and try to explain what is going on by means of the research and investigation element.

The results of this study include many clues about the pre-service social sciences teachers' level of knowledge in relation with the geography course. From this perspective, researches may be done on the changes intended on pre-service social sciences teachers' perceptions of the geography course, considering the objectives of the geography education. Moreover, the findings of this study will be providing different point of views on the subject, for the future researches as well. 
We wanted to show that metaphors are widely used in the field of education. It is seen that metaphors are quite useful in materializing abstract concepts. At the same time, it is seen that through metaphors, knowledge can be more permanent. Yet, it should be kept in mind that while using metaphors in class, any misunderstandings require to be avoided. They should be used carefully.

Considering the metaphors created by the participants, it is seen that the concept of geography can be explained with more than one metaphor. Öztürk (2007) applied a metaphor study of geography concept on the students of division of social sciences, primary education and science teaching; and Geçit and Gençer (2010) on students of division of primary education; and Aydın (2010) on students of division of middle school teaching. It has to be mentioned that this study provides more metaphors than above (Aydın, 2010-44 metaphors, Tuna and Budak, 2013-62 metaphors, Öztürk, 2007-44 metaphors (pre-service social sciences teachers), Kaya, 2013-42 metaphors), and pre-service social sciences teachers found geography interesting more than the others.

\section{References}

Alger, C. (2009). Secondary teachers' conceptual metaphors of teaching and learning: changes over the career span. Teaching and Teacher Education: An International Journal of Research and Studies, 25(5), 743-751. http://dx.doi.org/10.1016/j.tate.2008.10.004

Arslan, M. M., \& Bayrakçı, M. (2006). Metaforik düşünme ve öğrenme yaklaşımının eğitim-öğretim açısından incelenmesi. Millî Ĕgitim, 35(171), 100-108.

Aydın, F. (2010). Ortaöğretim öğrencilerinin coğrafya kavramına ilişkin sahip oldukları metaforlar, [Metaphors of Secondary school students had related to geography concept], Kuram ve Uygulamada Eğitim Bilimleri [Educational Sciences onTheory and Practice], 10(3), 1293-1322.

Aydın, F., \& Ünaldı, Ü. E. (2010). Coğrafya öğretmen adaylarinin “coğrafya” kavramına ilişkin algılarının metaforlar yardımiyla analizi. International Online Journal of Educational Sciences, 2(2), 600-622.

Aydoğdu, E. (2008). İlköğretim okullarındaki öğrenci ve ögretmenlerin sahip olduklarl okul algıları ile ideal okul algılarının metaforlar yardımıyla analizi. (Unpublished master's thesis), Eskisehir Osmangazi University, Institute of Science, Eskisehir.

Botha, E. (2009). Why metaphor matters in education. South African of Education, 29, 431-444.

Çapan, E. B. (2010). Öğretmen adaylarının üstün yetenekli öğrencilere ilişkin metaforik algıları. Uluslararası Sosyal Araştırmalar Dergisi, The Journal of International Social Research, 3(12), 140-154.

Çepni, S. (2010). Araştırma ve proje çalışmalarına giriş. [Introduction to research and project studies], Trabzon: Celepler matbaacılik.

Cerit, Y. (2008). Öğretmen kavramı ile ilgili metaforlara ilişkin öğrenci, öğretmen ve yöneticilerin görüşleri, [With the concept of teacher relevant to metaphors views of student teachers and administrators], Türk Eg̈itim Bilimleri Dergisi, Journal of Turkish Education Science, 6(4), 693-712.

Döş, İ. (2010). Aday öğretmenlerin müfettişlik kavramına ilişkin metafor algıları, Gaziantep Üniversitesi Sosyal Bilimler Dergisi, 9(3), 607-629.

Forceville, C. (2002). The identification of target and source in pictorial metaphors. Journal of Pragmatics, $34,1-14$. http://dx.doi.org/10.1016/S0378-2166(01)00007-8

Fraser, D. (2000). Sin, hope and optimism in children's metaphors, Australian Association for Research in Education Conference, December 4-7, Sydney- Australia.

Geçit, Y., \& Gençer, G. (2010). Sınıf öğretmenliği 1. sınıf öğrencilerinin coğrafya algılarının metafor yoluyla belirlenmesi (Rize Üniversitesi örneği) [1. Determination of primary school teaching 1st grade students' perception of geography through metaphors (University of Rize example)]. Marmara Coğrafya Dergisi,Marmara Geography Journal, 23, 1-19.

Guerrero, M., C. M., \& Villamil, O. S. (2002). Metaphorical conceptualizations of ELS teaching and learning. Language Teaching Research, 6(2), 95-120. http://dx.doi.org/ 10.1191/13621688021r101oa

Inbar, D. (1996). The free educational prison: Metaphors and images. Educational Research, 38(1) 77-92. http://dx.doi.org/10.1080/0013188960380106

Kalyoncu, R. (2013). Sınıf öğretmeni adaylarının “sanat eğitimi dersi” kavramına ilişkin metaforları, [Primary teachers” metaphors on the concept of "art education courses"], e-Journal of New World Sciences Academy NWSA-Education Sciences, 1C0574, 8(1), 90-102.) 
Kaya, H. (2011). The analysis of secondary education students perceptions towards "the world" concept. World Applied Sciences Journal, 12(2), 190-196.

Kaya, M. F. (2013). Sosyal bilgiler öğretmen adaylarının "küresel 1sınma" kavramına yönelik metafor algıları, [Metaphor perceptions of social studies teacher candidates towards the concept of "global warming"], Doğu Coğrafya Dergisi, Eastern Geographical Review, 18, 29 Sayfa 117-134.

Kövecses, Z. (2002). Metaphor-A Practical Introduction, Oxford University Pres, New York. Study. Journal of Academic Librarianship, 27(1). http://dx.doi.org/10.1017/S0047404503254051

Lakoff, G., \& Johnson, M. (2005). Metaforlar: Hayat, anlam ve dil (Çev: G. Yavuz Demir), Ankara: Paradigma Yayıncilık.

Miles, M. B., \& Huberman, A. M. (1994). Qualitative data analysis. Thousand Oaks, CA: Sage.

Nalçacı, A., \& Bektaş, F. (2012). Öğretmen adaylarının okul kavramına ilişkin algıları. [Teacher candidates’ perceptions regarding the concept of school], Ahi Evran Üniversitesi Kırşehir Eğitim Fakültesi Dergisi, 13(1), 239-258.

Öztürk, Ç. (2007). Sosyal bilgiler, sınıf ve fen bilgisi öğretmen adaylarının "coğrafya" kavramına yönelik metafor durumları. Metaphor status about the concept of 'geography' of prospective social science, science and classroom teachers, Ahi Evran Üniversitesi, Kırşehir Eğitim Fakültesi Dergisi, 8(2), 55-69.

Palmquist, R. A. (2001). Cognitive style and users' metaphors for the web: An exploratory study. Journal of Academic Librarianship, 27(1), 24-32. http://dx.doi.org/10.1016/S0099-1333(00)00205-6

Pishghadam, R., \& Navari, S. (2010). Examining Iranian language learners' perceptions of language education in formal and informal contexts: A quantitative study. The Modern Journal of Applied Linguistic, 1, 171-185.

Pishghadam, R., Torghabeh, R. A., \& Navari, S. (2009). Metaphor analysis of teachers' beliefs and conceptions of language teaching and learning in Iranian high schools and language institutes: A qualitative study. Iranian EFL Journal, 4, 6-40.

Saban, A. (2004). Giriş düzeyindeki sınıf öğretmeni adaylarının “öğretmen” kavramına ilişkin ileri sürdükleri metaforlar.[ Entry-level primary school teacher candidates' metaphors put forward on the concept of ' teacher'], Türk Eğitim Bilimleri Dergisi, Journal of Turkish Science Education, 2(2), 131-155.

Saban, A. (2008). İlköğretim I. kademe öğretmen ve öğrencilerinin bilgi kavramına ilişkin sahip oldukları metaforlar, The metaphors that primary school first grade teachers and students had on the concept of 'information'. İlköğretim Online, [Primary Education Online] 7(2), 421-455.

Saban, A. (2009). Öğretmen adaylarının öğrenci kavramına ilişkin sahip olduğu metaforlar, Metaphors that teacher candidates had on the concept of 'student', Türk Eğitim Bilimleri Dergisi, Journal of Turkish Science Education, 7(2), 281-326.

Saban, A., Koçbeker, B. N., \& Saban, A. (2006). Öğretmen adaylarının öğretmen kavramına ilişkin algılarının metafor analizi yoluyla incelenmesi. [Teacher candidates' perceptions of teacher concept examining by metaphor analysis], Kuram ve Uygulamada Eğitim Bilimleri,[Educational Sciences on Theory and Practice], 6, 461-522.

Salman, Y. (2003). Dilin Düşevreni: Ĕgretileme, Kitaplık, YKY, 65 (Ekim), 53-54, İstanbul.

Semerci, Ç. (2007). Program Geliştirme" Kavramına ilişkin metaforlarla yeni ilköğretim programlarına farklı bir bakış, [With the metaphors on the concept of "Program Development. A different view of the new primary school curriculum], C.Ü. Sosyal Bilimler Dergisi Aralık Sayısı. [C.U Journal of Social Sciences December Number], 31(2).

Şeyihoğlu, A., \& Gencer, G. (2011). Hayat bilgisi öğretiminde "Metafor" tekniğinin kullanımı, Türk Fen Eğitimi Dergisi. Journal of Turkish science education, 8(3), 83-100.

Shaw, D., Massengill, B., \& Mahlios, M. (2008). Preservice teachers' metaphors of teaching in relation to literacy beliefs. Teachers and Teaching: Theory and Practice, 14(1), 35-50. http://dx.doi.org/10.1080/13540600701837632

Şirin, E. F., Bektaş, F., Karaman, G., \& Aytan, G. K. (2012). Rafting katılımıılarının rafting kavramına ilişkin metaforik algıları.[Rafting participants' metaphoric perceptions concerning the concept of rafting], Beden Eğitimi ve Spor Bilimleri Dergisi, 6(2), 207-215.

Töremen, F., \& Döş, I. (2009). İlköğretim öğretmenlerinin müfettişlik kavramına ilişkin metaforik algıları. Metaphoric perceptions of primary school teachers' concept of inspection Kuram ve Uygulamada Eğitim Bilimleri, Educational Sciences on Theory and Practice, 9, 1973-2012.

Tuna, Y., \& Budak, F. (2013). Sosyal bilgiler öğretmen adaylarının "tarih" kavramına ilişkin algılarının mecazlar/ 
metaforlar yardımıyla analizi, [Social studies teacher candidates' the perception of "history" concept analysis with the help of metaphors], Adıyaman Üniversitesi Sosyal Bilimler Enstitüsü Dergisi, Sosyal Bilgiler Öğretimi Özel Sayıs1, 14 .

Yıldırım, A., \& Şimşek, H. (2013). Sosyal bilimlerde nitel araştırma yöntemleri. [Qualitative research methods in the Social Sciences], 9th Edition, Ankara: Seçkin.

Yıldırım, A., Ünal, A., \& Çelik, M. (2011). Öğretmen kavramına ilişkin öğretmen, yönetici ve müfettiş algılarının analizi. [The analysis of principle's, supervisor's and teacher's perception of the term "teacher"] International Journal of Human Sciences, 8(2), 92-109. 